\title{
Dampak Coronavirus Disease 2019 terhadap Sistem Kardiovaskular
}

\author{
Herick A. Willim, ${ }^{1}$ Infan Ketaren, ${ }^{2}$ Alice I. Supit ${ }^{2}$
}

\author{
${ }^{1}$ Rumah Sakit Umum Daerah Dr. Agoesdjam, Kabupaten Ketapang, Kalimantan Barat \\ ${ }^{2}$ Departemen Kardiologi dan Kedokteran Vaskular, Rumah Sakit Umum Daerah Dr. \\ Soedarso, Pontianak, Kalimantan Barat \\ Email: herick_alvenus@yahoo.co.id
}

\begin{abstract}
Coronavirus disease 2019 (COVID-19) caused by Severe Acute Respiratory Syndrome Coronavirus-2 (SARS-CoV-2) infection has become a pandemic. Patient with cardiovascular comorbidity has a higher risk of suffering more severe manifestation of COVID-19 associated with a higher mortality. Although dominated by respiratory clinical manifestation, COVID-19 may also cause severe cardiovascular disorders. Angiotensin converting enzyme 2 (ACE2) acts as a receptor of SARS-CoV-2. Patients of COVID-19 with cardiovascular comorbidities may experience more severe clinical manifestations, presumably due to higher ACE2 expression in this population. Cardiovascular complications in COVID-19 may include myocardial injury, myocarditis, acute myocardial infarction, acute heart failure, thromboembolism, and arrhythmias. Therefore, optimization of conservative medical therapy needs to be prioritized in patients with cardiovascular comorbidities. Emergency intervention can be considered in certain cases with hemodynamic instability.
\end{abstract}

Keywords: cardiovascular system, COVID-19, SARS-CoV-2, ACE2

\begin{abstract}
Abstrak: Coronavirus disease 2019 (COVID-19) telah merupakan pandemi yang disebabkan oleh infeksi Severe Acute Respiratory Syndrome Coronavirus-2 (SARS-CoV-2). Pasien dengan komorbid kardiovaskular berisiko lebih tinggi untuk mengalami manifestasi yang lebih berat jika terinfeksi COVID-19 dan berhubungan dengan mortalitas yang lebih tinggi. Meskipun didominasi oleh manifestasi klinis respiratorik, COVID-19 juga dapat menyebabkan gangguan kardiovaskular yang berat. Angiotensin converting enzyme 2 (ACE2) berperan sebagai reseptor SARS-CoV-2. Diduga pasien dengan penyakit kardiovaskular dapat bermanifestasi klinis lebih berat karena ekspresi ACE2 yang lebih tinggi pada populasi ini. Komplikasi kardiovaskular pada COVID-19 dapat meliputi jejas miokardium, miokarditis, infark miokard akut, gagal jantung akut, tromboemboli, dan aritmia. Pada pasien dengan komorbid kardiovaskular, optimalisasi terapi medis konservatif perlu diprioritaskan. Tindakan intervensi darurat dapat dipertimbangkan pada kasus tertentu dengan instabilitas hemodinamik.
\end{abstract}

Kata kunci: sistem kardiovaskular, COVID-19, SARS-CoV-2, ACE2

\section{Pendahuluan}

Penyakit koronavirus 2019 (coronavirus disease 2019/COVID-19) merupakan penyakit infeksi baru yang disebabkan oleh Severe Acute Respiratory Syndrome Coronavirus-2 (SARS-CoV-2). Awalnya penyakit ini dikenal dengan nama 2019 novel coronavirus (2019-nCoV). COVID-19 pertama kali dilaporkan pada akhir Desember 2019 di Wuhan, Provinsi Hubei, Tiongkok. ${ }^{1}$
World Health Organization (WHO) menetapkan wabah COVID-19 sebagai Public Health Emergency of International Concern (PHEIC) pada tanggal 30 Januari 2020, namun kasus ini semakin menyebar secara cepat hingga WHO menetapkan COVID-19 sebagai pandemi pada tanggal 11 Maret $2020 .^{2}$

SARS-CoV-2 merupakan virus singlestranded RNA (ssRNA) beramplop dan 
diketahui sebagai strain coronavirus ketujuh yang dapat menginfeksi manusia. Virus ini berbeda dengan coronavirus lain yang diketahui menyebabkan infeksi respiratorik ringan $(229 \mathrm{E}, \mathrm{OC} 43, \mathrm{NL63}$, dan HKU1), namun mirip dengan Severe Acute Respiratory Syndrome Coronavirus (SARS$\mathrm{CoV})$ dan Middle East Respiratory Syndrome Coronavirus (MERS-CoV) yang dapat menyebabkan infeksi respiratorik berat. ${ }^{3,4}$ SARS-CoV-2 diduga berasal dari kelelawar karena memiliki 89-96\% kemiripan nukleotida dengan coronavirus kelelawar. ${ }^{5}$ Seperti halnya dengan SARS dan MERS, diduga SARS-CoV-2 berpindah dari kelelewar ke hospes perantara (kemungkinan trenggiling, dengan kemiripan $91 \%$ nukleotida) dan kemudian berpindah ke manusia. ${ }^{6}$

Virus SARS-CoV-2 menyebar secara dominan melalui droplet respiratorik yang dihasilkan saat bersin atau batuk, dan dapat juga secara tidak langsung melalui objek atau permukaan yang terkontaminasi. Transmisi dapat terjadi dari pasien simtomatik maupun asimtomatik. Masa inkubasi COVID-19 sekitar 2-14 hari (rerata 5 hari). Pasien COVID-19 mengalami gejala utama demam, batuk, dan sesak napas. Gejala lain dapat berupa mialgia, anoreksia, malaise, nyeri menelan, mual/muntah, kongesti nasal, sakit kepala, dan diare. Pada kasus berat pasien dapat mengalami pneumonia berat, acute respiratory distress syndrome (ARDS), sepsis, syok sepsis, dan multiple organ dysfunction syndrome (MODS). ${ }^{7}$

Komorbid kardiovaskular umum ditemukan pada pasien COVID-19 dan berhubungan dengan risiko morbiditas dan mortalitas yang lebih tinggi dibandingkan pasien tanpa komorbid. Meskipun manifestasi klinis COVID-19 didominasi oleh gejala respiratorik, pasien dapat mengalami gangguan kardiovaskular berat. $^{3}$ Pengetahuan tentang dampak COVID-19 terhadap sistem kardiovaskular penting untuk dipahami, terutama bagi klinisi yang terlibat dalam penanganan pasien COVID-19. Penulisan artikel ini bertujuan untuk memberikan pemahaman tentang dampak COVID-19 terhadap sistem kardiovaskular.

\section{Peran Angiotensin Converting Enzyme 2 dalam Patogenesis COVID-19}

Sistem renin-angiotensin (SRA) berperan penting dalam sistem kardiovaskular dan berkontribusi terhadap penyakit kardiovaskular seperti hipertensi, penyakit jantung koroner, dan gagal jantung. Komponen SRA terdiri dari angiotensinogen, renin, angiotensin II, reseptor angiotensin II (AT1 dan AT2), dan angiotensin-converting enzyme (ACE). Telah diketahui bahwa ACE merupakan enzim yang berperan dalam katalisis konversi angiotensin I menjadi angiotensin II yang berperan dalam vasokonstriksi dan peningkatan tekanan darah. Pada dua dekade terakhir, ditemukan homolog baru ACE, yaitu ACE2. ${ }^{8}$ Bahan ini merupakan enzim counterregulatory yang dapat mendegradasi angiotensin II menjadi angiotensin(1-7) yang bersifat vasodilator, sehingga mengu-rangi efek vasokonstriksi, retensi natrium, dan fibrosis. Meskipun angiotensin II merupakan substrat primer ACE2, enzim ini juga dapat mendegradasi angiotensin I menjadi angiotensin-(1-9) dan berperan dalam hidrolisis peptida. Aksis ACE2/ angiotensin-(1-7) berperan dalam mekanisme fisiologik protektif melawan aktivasi SRA klasik. ${ }^{8,9}$

Selain berperan penting dalam sistem kardiovaskular, ACE2 juga berperan sebagai reseptor fungsional coronavirus yang dapat mengikat protein spike permukaan virus secara langsung. SARS-CoV-2 memasuki sel inang melalui reseptor ACE2 yang banyak terdapat di paru-paru (terutama pada sel alveolus tipe II). ACE2 juga banyak terdapat jantung. Selain itu, ACE2 juga ditemukan di epitel usus, endotel pembuluh darah, dan ginjal; hal ini menjadi dasar mekanisme disfungsi multiorgan yang dapat terjadi pada infeksi SARS-CoV-2. ${ }^{3}$ Pasien dengan komorbid kardiovaskular lebih rentan terinfeksi SARS-CoV-2 dan dapat mengalami manifestasi klinis yang lebih berat diduga karena berhubungan dengan meningkatnya ekspresi ACE2 pada kelompok ini dibandingkan pasien tanpa komorbid kardiovaskular. ${ }^{8,10}$

Infeksi SARS-CoV-2 terjadi ketika protein spike permukaan virus tersebut 
mengikat reseptor ACE2 setelah diaktivasi oleh transmembrane protease serine 2 (TMPRSS2). ${ }^{3}$ Pengikatan protein spike virus pada reseptor ACE2 akan menyebabkan terjadinya down regulation aktivitas ACE2 pada permukaan sel sehingga efek protektif enzim tersebut menjadi hilang. Infeksi dan replikasi virus yang berkelanjutan akan menyebabkan ekspresi ACE2 semakin berkurang. Down-regulation aktivitas ACE2 di paru-paru dapat memfasilitasi infiltrasi neutrofil sebagai respon terhadap endotoksin dan menyebabkan akumulasi unopposed angiotensin II dan aktivasi lokal SRA berlebihan yang dapat memicu terjadinya jejas paru dan miokardium. ${ }^{9}$

\section{Patogenesis Gangguan Kardiovaskular pada COVID-19}

Meskipun sistem respirasi merupakan target primer infeksi SARS-CoV-2, sistem kardiovaskular juga dapat terlibat. Berikut ini diuraikan beberapa mekanisme patogenesis terjadinya gangguan kardiovaskular pada COVID-19.

\section{Jejas miokardium}

SARS-CoV-2 memasuki sel manusia dengan mengikat ACE2 yang banyak terdapat di paru-paru dan jantung. Pengikatan SARS-CoV-2 pada ACE2 dapat mengubah jalur sinyal normal ACE2. Jejas miokardium dapat terjadi melalui mekanisme keterlibatan virus secara langsung pada kardiomiosit atau efek inflamasi sistemik. ${ }^{11}$

\section{Inflamasi sistemik}

COVID-19 dapat menyebabkan respon inflamasi sistemik berlebihan dan badai sitokin yang dapat menyebabkan terjadinya jejas dan gangguan pada berbagai organ, termasuk jantung. Berbagai studi telah menunjukkan tingginya kadar sitokin proinflamasi pada pasien COVID-19 berat atau kritis. $^{11}$

\section{Ketidakseimbangan kebutuhan dan pasok- an oksigen miokardium}

Peningkatan kebutuhan oksigen akibat infeksi sistemik dan hipoksia yang disebabkan COVID-19 dapat menyebabkan ketidak- seimbangan kebutuhan dan pasokan oksigen yang dapat memicu terjadinya jejas miokardium. ${ }^{11}$

\section{Ruptur plak dan trombosis koroner}

Inflamasi sistemik dan peningkatan shear stress akibat aliran darah koroner yang meningkat dapat memicu terjadinya ruptur plak aterosklerosis sehingga terjadi trombosis dan infark miokard akut. ${ }^{11}$

\section{Koagulopati}

Hiperinflamasi sistemik dan badai sitokin dapat menyebabkan peningkatan aktivasi kaskade koagulasi. Keadaan hiperkoagulasi dapat meningkatkan risiko terjadinya trombosis dan tromboemboli baik pada vena maupun arteri. ${ }^{12}$

\section{Ketidakseimbangan elektrolit}

Ketidakseimbangan elektrolit dapat terjadi pada penyakit kritis dan memicu terjadinya aritmia. Kejadian hipokalemia banyak dilaporkan pada COVID-19. Pengikatan SARS-CoV-2 pada ACE2 menyebabkan berkurangnya aksi counterregulatory pada SRA. Hal ini menyebabkan meningkatnya reabsorpsi natrium dan air sehingga terjadi peningkatan tekanan darah dan ekskresi kalium. Hipokalemia pada COVID-19 dapat memicu terjadinya disfungsi otot respirasi dan aritmia ventrikel yang dapat mengancam nyawa. ${ }^{13}$

\section{Komorbid Kardiovaskular pada COVID-19}

Pasien dengan komorbid kardiovaskular seperti hipertensi dan penyakit jantung koroner (PJK) lebih berisiko untuk mengalami manifestasi lebih berat jika terinfeksi SARS-CoV-2 dan berkontribusi terhadap sebagian besar kasus kematian pada COVID-19. Hal ini diduga karena ekspresi ACE2 yang lebih tinggi pada penderita penyakit kardiovaskular. ${ }^{14}$ Pasien berusia >60 tahun yang terinfeksi SARSCoV-2 dapat mengalami manifestasi sistemik dan pneumonia yang lebih parah dibandingkan pasien berusia $\leq 60$ tahun dan diperberat oleh adanya komorbid penyakit kardiovaskular. Faktor risiko COVID-19 
berat lainnya meliputi diabetes, penyakit paru obstruktif kronis, dan keganasan. ${ }^{10}$

Pasien dengan riwayat penyakit kardiovaskular dapat menjadi tidak stabil pada keadaan terinfeksi SARS-CoV-2 sebagai konsekuensi dari ketidakseimbangan antara kebutuhan metabolik yang meningkat karena infeksi dan berkurangnya cadangan jantung. Pasien dengan sindrom koroner akut (SKA) yang terinfeksi SARS-CoV-2 seringkali memiliki prognosis buruk. Pada pasien SKA, cadangan fungsional jantung berkurang akibat iskemia atau nekrosis miokard, sehingga ketika terinfeksi SARS-CoV-2, insufisiensi jantung dapat terjadi, menyebabkan perburukan mendadak. Beberapa pasien COVID-19 di Wuhan memiliki riwayat SKA, yang berhubungan dengan semakin parahnya penyakit dan memiliki angka mortalitas yang tinggi. ${ }^{10,15}$

Sebuah studi di Tiongkok terhadap 44.672 pasien terkonfirmasi COVID-19 melaporkan bahwa $12,8 \%$ pasien memiliki riwayat hipertensi dan $4,2 \%$ pasien memiliki riwayat penyakit kardiovaskular seperti PJK. Pada populasi tersebut, $80,9 \%$ pasien dilaporkan mengalami derajat ringan tanpa mortalitas, 13,8\% mengalami derajat berat tanpa mortalitas, dan 4,7\% mengalami kritis dengan case fatality rate (CFR) $49 \%$. Secara keseluruhan, diperoleh CFR sebesar 2,3\%. Mortalitas COVID-19 meningkat dengan bertambahnya usia, dengan CFR $1,3 \%$ pada pasien usia $50-59$ tahun, $3,6 \%$ pada pasien usia 60-69 tahun, 8\% pada pasien usia 70-79 tahun, dan $14,8 \%$ pada pasien usia $\geq 80$ tahun. CFR pada pasien tanpa komorbid sebesar $0,9 \%$. CFR lebih tinggi pada pasien dengan komorbid, yaitu $10,5 \%$ pada penyakit kardiovaskular, 7,3\% pada diabetes, $6,3 \%$ pada penyakit paru kronis, dan $6 \%$ pada hipertensi. ${ }^{16}$

Sebuah studi di Wuhan terhadap 138 pasien terkonfirmasi COVID-19 melaporkan bahwa $46,4 \%$ pasien memiliki 1 atau lebih komorbid, meliputi hipertensi 31,2\%, penyakit kardiovaskular $14,5 \%$, diabetes $10,1 \%$, dan keganasan $7,2 \% .{ }^{17}$ Studi lain di Wuhan terhadap 41 pasien terkonfirmasi COVID-19 melaporkan bahwa 32\% pasien memiliki komorbid, meliputi diabetes $20 \%$, hipertensi $15 \%$, dan penyakit kardiovaskular $15 \% .^{18}$

\section{Komplikasi Kardiovaskular pada COVID- 19}

COVID-19 dapat memicu terjadinya komplikasi kardiovaskular yang baru. Risiko komplikasi ini lebih tinggi pada pasien usia tua atau memiliki komorbid kardiovaskular. Komplikasi yang dapat terjadi meliputi jejas miokardium, miokarditis, infark miokard akut (IMA), gagal jantung akut, tromboemboli, dan aritmia. ${ }^{19}$

\section{Jejas miokardium dan miokarditis}

Jejas miokardium ditandai dengan meningkatnya biomarker jantung (troponin), telah banyak dilaporkan pada COVID19. Pasien dengan komorbid kardiovaskular seperti hipertensi, penyakit jantung koroner, dan kardiomiopati memiliki risiko lebih tinggi untuk mengalami jejas miokardium. ${ }^{20}$ Shi et $\mathrm{al}^{21}$ melaporkan tingginya kejadian jejas miokardium pada 416 pasien terkonfirmasi COVID-19 yang dirawat. Pada populasi penelitian tersebut, sebanyak 82 pasien $(19,7 \%)$ mengalami jejas miokardium yang ditandai dengan meningkatnya kadar biomarker jantung (high sensitivity cardiac troponin I - hsTnI) diatas persentil 99 nilai batas atas. Pasien dengan hsTnI yang meningkat berusia lebih tua, memiliki lebih banyak komorbiditas, dan memiliki kadar leukosit, $N$-terminal pro-brain natriuretic peptides (NT-proBNP), $C$ reactive protein (CRP), dan prokalsitonin yang lebih tinggi, namun memiliki kadar limfosit yang lebih rendah. Pasien dengan jejas miokardium memiliki insiden ARDS yang lebih tinggi $(58,5 \%$ vs $14,7 \%)$ dan tingkat mortalitas yang lebih tinggi $(51,2 \%$ vs $4,5 \%$ ) dibandingkan pasien tanpa jejas miokardium.

Mekanisme jejas miokardium yang disebabkan oleh COVID-19 belum sepenuhnya dipahami. Jejas miokardium mungkin diakibatkan oleh miokarditis virus dan/atau proses iskemia. Penelitian sebelumnya menunjukkan bahwa pada $35 \%$ pasien dengan infeksi SARS-CoV, genom SARS-CoV terdeteksi di jantung. ${ }^{22}$ Hal ini meningkatkan 
dugaan bahwa virus dapat menginfeksi miokardium secara langsung serta menyebabkan miokarditis dan kerusakan miokardium. SARS-CoV-2 dapat memiliki mekanisme yang sama dengan SARS-CoV karena keduanya memiliki genom yang homolog. Jejas miokardium dapat berhubungan dengan patogenesis inflamasi yang terjadi selama proses penyakit. Badai sitokin dan respon imun berlebihan yang dapat terjadi pada COVID-19 juga berkontribusi terhadap terjadinya jejas miokardium dan keparahan penyakit. ${ }^{18,20}$

\section{Infark miokard akut}

Keterlibatan koroner dan IMA dapat terjadi pada COVID-19 dengan berbagai meka-nisme. ACE2 yang terdapat pada sel endotel vaskular dapat menyebabkan infeksi virus secara langsung. Hal ini dapat memicu terjadinya instabilitas dan ruptur plak, serta infark miokard tipe 1. Instabilitas dan ruptur plak juga dapat dipicu oleh respon inflamasi sistemik berat. Peningkatan kebutuhan kardiometabolik pada pasien yang sakit kritis dapat menyebabkan terjadinya infark miokard tipe II akibat ketidakseimbangan kebutuhan dan pasokan oksigen. Demam dan takikardia yang disebabkan sepsis dan hipoksia akibat gangguan paru dapat semakin memperburuk fungsi jantung. ${ }^{23}$

\section{Gagal jantung akut}

Gagal jantung akut dapat menjadi manifestasi primer pada COVID-19. Studi yang dilakukan oleh Zhou et $\mathrm{al}^{24}$ terhadap 191 pasien terkonfirmasi COVID-19 menemukan gagal jantung akut terjadi pada $23 \%$ pasien dan berubungan dengan peningkatan mortalitas. Studi lainnya menemukan kejadian gagal jantung akut pada $24 \%$ pasien dan hampir separuh diantaranya tidak memiliki riwayat hipertensi atau penyakit kardio-vaskular sebelumnya. ${ }^{25}$ Hingga saat ini belum diketahui apakah gagal jantung akut pada COVID-19 terjadi akibat kardiomiopati onset baru atau eksaserbasi dari gagal jantung yang tidak terdiagnosis sebelumnya. Penting untuk dicermati bahwa gagal jantung akut dapat menjadi komplikasi potensial yang terjadi pada COVID-19 ketika memberikan terapi cairan intravena. Pemberian cairan yang berlebihan perlu dihindari pada keadaan ini. ${ }^{26}$

\section{Tromboemboli}

Gangguan koagulasi sering ditemukan pada pasien COVID-19 berat dan berhubungan dengan prognosis buruk. Peningkatan D-dimer, pemanjangan prothrombin time (PT) dan activated partial thromboplastin time (APTT), serta trombositopenia merupakan parameter koagulopati yang sering ditemukan. Hiperinflamasi sistemik dan jejas endotel diduga menjadi mekanisme terjadinya koagulopati pada COVID-19. Koagulopati menyebabkan keadaan hiperkoagulasi yang dapat meningkatkan risiko terjadinya komplikasi trombosis dan tromboemboli vena maupun arteri. ${ }^{27}$ Tromboemboli vena merupakan komplikasi trombosis yang paling sering ditemukan pada COVID-19 berat. Studi yang dilakukan oleh Klok et $\mathrm{al}^{28}$ terhadap 184 pasien COVID-19 berat yang dirawat di unit perawatan intensif melaporkan kejadian tromboemboli vena pada $27 \%$ pasien, dengan mayoritas di antaranya ialah emboli paru.

\section{Aritmia}

Studi yang dilakukan oleh Guo et $\mathrm{al}^{20}$ terhadap 187 pasien terkonfirmasi COVID19 menemukan kejadian aritmia maligna (takikardi ventrikel/fibrilasi ventrikel) pada $16,7 \%$ pasien. Kejadian aritmia ini lebih banyak ditemukan pada pasien yang mengalami jejas miokardium. Berbagai mekanisme dapat memicu terjadinya aritmia pada COVID-19, meliputi jejas miokardium, miokarditis, iskemia/infark miokard, gangguan elektrolit (terutama hipokalemia), efek samping terapi obat (misalnya azitromisin dan klorokuin/hidroksiklorokuin) yang dapat menyebabkan pemanjangan interval QTc dan memicu terjadinya takiaritmia ventrikel, serta demam yang dapat memicu kasus kanalopati jantung seperti sindrom Brugada dan sindrom QT panjang. ${ }^{29}$

\section{Pertimbangan Kardiovaskular dalam Terapi Obat}

Hingga saat ini belum ditemukan obat 
spesifik untuk COVID-19. Tatalaksana umumnya bersifat suportif sesuai kebutuhan pasien. Obat-obatan yang saat ini sedang banyak diteliti meliputi golongan antivirus (misalnya remdesivir, lopinavir/ritonavir, dan favipiravir), antibiotik (misalnya azitromisin), dan antimalaria (misalnya klorokuin/hidroksiklorokuin). Sebagian obatobatan tersebut memiliki potensial aritmogenik dan dapat berinteraksi dengan obatobatan kardiovaskular seperti antihipertensi, antiaritmia, antikoagulan, antiplatelet, dan statin, sehingga penggunaannya perlu dengan berhati-hati. ${ }^{26}$

Azitromisin dan klorokuin/hidroksiklorokuin merupakan obat potensial yang banyak digunakan di Indonesia. Penggunaan azitromisin dan klorokuin/hidroksiklorokuin telah dikaitkan dengan risiko terjadinya pemanjangan interval QTc yang dapat menginduksi terjadinya torsades de pointes (TdP). Pasien perlu diberikan penjelasan terkait indikasi dan efek samping potensial yang dapat terjadi sebelum diberikan azitromisin dan klorokuin/hidroksiklorokuin secara bersamaan. Pemeriksaan EKG harus dilakukan sebelum pemberian terapi dan selanjutnya dilakukan pemeriksaan EKG serial untuk memantau interval QTc. Pasien dengan QTc yang memanjang (>500 mdet pada QRS sempit atau $\geq 550$ mdet pada QRS lebar) harus dipertimbangkan manfaat dan risiko terjadinya $\mathrm{TdP} .{ }^{30}$

Beberapa waktu ini, terdapat isu terkait keamanan penggunaan obat golongan $\mathrm{ACE}$ inhibitors (ACEi) dan angiotensin receptor blockers (ARB) selama pandemi COVID19. Obat ini diduga dapat menyebabkan peningkatan ekspresi ACE2 pada berbagai jaringan, termasuk jantung. Karena SARSCoV-2 mengikat ACE2 untuk dapat memasuki sel manusia, sehingga dikhawatirkan terdapat potensi peningkatan risiko terjadinya COVID-19 atau mengalami derajat penyakit yang lebih berat pada pasien yang telah mendapatkan terapi ACEi atau ARB. Di sisi lain, penghentian mendadak penggunaan ACEi atau ARB pada pasien dengan penyakit kardiovaskular seperti hipertensi, penyakit jantung koroner, atau gagal jantung dapat menyebabkan efek yang merugikan. ${ }^{31}$
Hingga saat ini belum terdapat data eksperimental maupun uji klinis yang membuktikan keuntungan atau kerugian penggunaan $\mathrm{ACEi}, \mathrm{ARB}$, ataupun golongan antagonis renin-angiotensin-aldosterone system (RAAS) lainnya pada COVID-19 ataupun pasien dengan riwayat penyakit kardiovaskular yang terinfeksi COVID-19. Heart Failure Society of America (HFSA), American College of Cardiology (ACC), dan American Heart Association (AHA) merekomendasikan untuk tetap melanjutkan terapi antagonis RAAS pada pasien yang telah terindikasi menerima obat tersebut dan telah terbukti bermanfaat, seperti pada gagal jantung, hipertensi, atau penyakit jantung iskemik. Pada pasien dengan penyakit kardiovaskular yang terdiagnosis COVID19, keputusan tatalaksana bersifat individual, perlu dipertimbangkan berdasarkan status hemodinamik dan presentasi klinis pasien. Dengan demikian, dianjurkan untuk tidak menambah atau mengurangi pengobatan terkait antagonis RAAS, diluar pedoman praktik klinis standar. ${ }^{32}$

\section{Implikasi dalam Praktik Klinis}

Pasien dengan komorbid kardiovaskular berisiko yang lebih tinggi untuk morbiditas dan mortalitas terkait COVID-19 sehingga pasien harus memahami rekomendasi WHO tentang proteksi dasar terhadap COVID-19, meliputi cara cuci tangan secara teratur dengan hand rub berbasis alkohol atau sabun dan air; hindari menyentuh daerah mata, hidung, dan mulut; melakukan etika batuk atau bersin; gunakan masker; dan social distancing dengan menjaga jarak. Petugas penanganan COVID-19 harus menggunakan alat pelindung diri yang lengkap sebelum menangani pasien. Pengunaan telepon atau telemedicine dapat menjadi alternatif kunjungan rutin ke fasilitas kesehatan bagi pasien dengan penyakit kardiovaskular stabil di daerah risiko tinggi penularan COVID$19.33,34$

Klinisi perlu memahami bahwa dalam konteks COVID-19, tanda dan gejala klasik infark miokard akut mungkin menjadi tidak khas. Pada pasien dengan gagal jantung atau volume overload, pemberian cairan yang 
berlebihan perlu dihindari dan diperlukan pemantauan balans cairan secara berkala. Protokol spesifik terhadap tatalaksana infark miokard akut perlu dikembangkan dalam konteks pandemi COVID-19, baik untuk pasien dengan maupun tanpa diagnosis COVID-19. Perhatian khusus perlu diberikan pada tindakan percutaneous coronary intervention (PCI) dan coronary artery bypass graft (CABG), meliputi protokol pembatasan laboratorium kateterisasi jantung, peningkatan proteksi personal, dan sterilisasi pasca prosedur. Pada setiap tindakan intervensi harus dilakukan penilaian terhadap keuntungan dan kerugian akan risiko terjadinya infeksi nosokomial. ${ }^{34}$

Selama pandemi, setiap pasien perlu dievaluasi terhadap kemungkinan COVID19 dan diagnosis banding secara komprehensif (sesak, penurunan saturasi oksigen dan syok yang diakibatkan penyakit kardiovaskular dapat pula ditemukan pada infeksi COVID-19 kritis). Pasien dengan penyakit kardiovaskular berat yang telah disingkirkan kemungkinan COVID-19 dapat ditangani secara lokal, sedangkan pasien yang terkonfirmasi COVID-19 harus dirujuk segera ke rumah sakit rujukan COVID-19 untuk karantina dan tatalaksana lanjutan. ${ }^{35}$

Optimalisasi terapi medis konservatif perlu diprioritaskan pada pasien dengan penyakit kardiovaskular berat yang belum dapat disingkirkan kemungkinan COVID19 demi mencegah transmisi SARS-CoV-2. Tindakan intervensi darurat dapat dipertimbangkan pada kasus tertentu seperti IMA dengan instabilitas hemodinamik, diseksi aorta akut Stanford tipe A atau tipe B kompleks, bradiaritmia dengan instabilitas hemodinamik yang membutuhkan pacemaker, dan emboli paru dengan instabilitas hemodinamik. ${ }^{35}$

\section{Simpulan}

Pasien dengan komorbid kardiovaskular memiliki risiko lebih tinggi untuk mengalami manifestasi lebih berat jika terinfeksi COVID-19 karena diduga berhubungan dengan meningkatnya ekspresi ACE2 pada kelompok ini dibandingkan pasien tanpa komorbid kardiovaskular.
Meskipun bermanifestasi utama pada sistem respiratorik, COVID-19 dapat memicu komplikasi kardiovaskular seperti jejas miokardium, miokarditis, infark miokard akut, gagal jantung akut, tromboemboli, dan aritmia. Selama pandemi, pencegahan dan kontrol merupakan prioritas yang harus dilakukan. Pada pasien penyakit kardiovaskular, optimalisasi terapi medis konservatif perlu diprioritaskan namun tindakan intervensi darurat dapat dipertimbangkan pada kasus tertentu dengan instabilitas hemodinamik.

\section{Konflik Kepentingan}

Penulis menyatakan tidak terdapat konflik kepentingan dalam studi ini.

\section{DAFTAR PUSTAKA}

1. Zhou P, Yang XL, Wang XG, Hu B, Zhang L, Zhang W, et al. A pneumonia outbreak associated with a new coronavirus of probable bat origin. Nature. 2020; 579(7798):270-3

2. World Health Organization. Coronavirus disease 2019 (COVID-19) situation report - 67 [Internet]. 2020 [cited 2020 Sept 21]. Available from: https://www. who.int/docs/default-source/ coronaviruse/situation-reports/ 20200327-sitrep-67-covid-19.pdf? sfvrsn=b65f68eb_4.

3. Clerkin KJ, Fried JA, Raikhelkar J, Sayer G, Griffin JM, Masoumi A, et al. COVID19 and cardiovascular disease. Circulation. 2020;141(20):1648-55.

4. Song Z, Xu Y, Bao L, Zhang L, Yu P, Qu Y, et al. From SARS to MERS, thrusting coronaviruses into the spotlight. Viruses. 2019;11(1):59.

5. Andersen KG, Rambaut A, Lipkin WI, Holmes EC, Garry RF. The proximal origin of SARS-CoV-2. Nat Med. 2020;26(4): 450-2.

6. Zhang T, Wu Q, Zhang Z. Probable pangolin origin of SARS-CoV-2 associated with the COVID-19 outbreak. Curr Biol. 2020;30(7):1346-51.

7. Singhal T. A review of coronavirus disease2019 (COVID-19). Indian J Pediatr. 2020; 87(4):281-6.

8. Chen L, Hao G. The role of angiotensinconverting enzyme 2 in corona viruses/ influenza viruses and cardiovascular 
disease. Cardiovasc Res. 2020;0:1-5.

9. Vaduganathan $M$, Vardeny $O$, Michel $T$, Mcmurray JJV, Pfeffer MA, Solomon SD. Renin-angiotensin-aldosterone system inhibitors in patients with Covid-19. N Engl J Med. 2020;382(17):1653-9.

10. Zheng YY, Ma YT, Zhang JY, Xie X. COVID-19 and the cardiovascular system. Nat Rev Cardiol. 2020;17(5): 259-60.

11. Bansal M. Cardiovascular disease and COVID-19. Diabetes Metab Syndr. 2020;14(3):247-50.

12. Marchandot B, Sattler L, Jesel L, Matsushita K, Schini-Kerth V, Grunebaum L, et al. COVID-19 related coagulopathy: a distinct entity? J Clin Med. 2020;9(6): 1651.

13. Chen D, Li X, Song Q, Hu C, Su F, Dai J, et al. Assessment of hypokalemia and clinical characteristics in patients with corona-virus disease 2019 in Wenzhou, China. JAMA Netw Open. 2020;3(6): e2011122.

14. Costa IBSDS, Bittar CS, Rizk SI, Filho AEDA, Santos KAQ, Machado TIV, et al. The heart and COVID-19: what cardiologists need to know. Arq Bras Cardiol. 2020; 114(5):805-16.

15. Xiong TY, Redwood S, Prendergast B, Chen M. Coronaviruses and the cardiovascular system: acute and long-term implications. Eur Heart J. 2020;41(19): 1798-800.

16. Epidemiology Working Group for NCIP Epidemic Response, Chinese Center for Disease Control and Prevention. The epidemiological characteristics of an outbreak of 2019 novel coronavirus diseases (COVID-19) in China. Zhonghua Liu Xing Bing Xue Za Zhi. 2020;41(2):145-51.

17. Wang D, Hu B, Hu C, Zhu F, Liu X, Zhang J, et al. Clinical characteristics of 138 hospitalized patients with 2019 novel coronavirus-infected pneumonia in Wuhan, China. JAMA. 2020;323(11): 1061-9.

18. Huang C, Wang Y, Li X, Ren L, Zhao J, Hu Y, et al. Clinical features of patients infected with 2019 novel coronavirus in Wuhan, China. Lancet. 2020;395 (10223):497-506.

19. Matsushita K, Marchandot B, Jesel L, Ohlmann P, Morel O. Impact of
COVID-19 on the cardiovascular system: a review. J Clin Med. 2020; 9(5):1407.

20. Guo T, Fan Y, Chen M, Wu X, Zhang L, He $\mathrm{T}$, et al. Cardiovascular implications of fatal outcomes of patients with coronavirus disease 2019 (COVID-19). JAMA Cardiol. 2020;5(7):811-8.

21. Shi S, Qin M, Shen B, Cai Y, Liu T, Yang F, et al. Association of cardiac injury with mortality in hospitalized patients with COVID-19 in Wuhan, China. JAMA Cardiol. 2020;5(7):802-10.

22. Oudit GY, Kassiri Z, Jiang C, Liu PP, Poutanen SM, Penninger JM, et al. SARS-coronavirus modulation of myocardial ACE2 expression and inflammation in patients with SARS. Eur J Clin Invest. 2009;39(7):618-25.

23. Bandyopadhyay D, Akhtar T, Hajra A, Gupta M, Das A, Chakraborty S, et al. COVID19 pandemic: cardiovascular complications and future implications. Am J Cardiovasc Drugs. 2020;20(4):311-24.

24. Zhou F, Yu T, Du R, Fan G, Liu Y, Liu Z, et al. Clinical course and risk factors for mortality of adult inpatients with COVID-19 in Wuhan, China: a retrospective cohort study. Lancet. 2020; 395(10229):1054-62.

25. Chen T, Wu D, Chen H, Yan W, Yang D, Chen $\mathrm{G}$, et al. Clinical characteristics of 113 deceased patients with coronavirus disease 2019: retrospective study. BMJ. 2020;368:m1091.

26. Long B, Brady WJ, Koyfman A, Gottlieb M. Cardiovascular complications in COVID-19. Am J Emerg Med. 2020; 38(7):1504-7.

27. Shi W, Lv J, Lin L. Coagulopathy in COVID19: focus on vascular thrombotic events. J Mol Cell Cardiol. 2020;146:32-40.

28. Klok FA, Kruip MJHA, van der Meer NJM, Arbous MS, Gommers DAMPJ, Kant $\mathrm{KM}$, et al. Incidence of thrombotic complications in critically ill ICU patients with COVID-19. Thromb Res. 2020;191:145-7.

29. Goha A, Mezue K, Edwards P, Nunura F, Baugh D, Madu E. COVID-19 and the heart: an update for clinicians. Clin Cardiol. 2020;10.1002/clc.23406.

30. Burhan E, Susanto AD, Nasution SA, Ginanjar E, Pitoyo CW, Susilo A, et al. Pedoman tatalaksana COVID-19 Edisi 2. Jakarta: 
PDPI, PERKI, PAPDI, PERDATIN, IDAI; 2020.

31. Kow CS, Zaidi STR, Hasan SS. Cardiovascular disease and use of reninangiotensin system inhibitors in COVID-19. Am J Cardiovasc Drugs. 2020;20(3):217-21.

32. Heart Failure Society of America, American College of Cardiology, American Heart Association. HFSA/ACC/AHA statement addresses concerns re: using RAAS antagonists in COVID-19 [Internet]. 2020 [cited 2020 Sept 21]. Available from: https://www.acc.org/ latest-in-cardiology/articles/2020/03/17/ 08/59/hfsa-acc-aha-statement-addressesconcerns-re-using-raas-antagonists-incovid-19.

33. World Health Organization. Rational use of personal protective equipment for coronavirus disease 2019 (COVID-19) [Internet]. 2020 [cited 2020 Sept 21]. Available from: https://apps.who.int/ iris/bitstream/handle/10665/331215/W HO-2019-nCov-IPCPPE_use-2020.1eng.pdf.

34. American College of Cardiology. COVID-19 clinical guidance for the cardiovascular care team [Internet]. 2020 [cited 2020 Sept 21]. Available from: https://www. acc.org/latest-in-cardiology/articles/ 2020/03/06/15/01/acc-issues-covid-19clinical-guidance-for-the-cv-care-team.

35. Han Y, Zeng H, Jiang H, Yang Y, Yuan Z, Cheng X, et al. CSC expert consensus on principles of clinical management of patients with severe emergent cardiovascular diseases during the COVID-19 epidemic. Circulation. 2020;141(20): e810-6. 